\title{
Bir Aile Hekimliği Polikliniğinde 5-18 yaş arası Çocuklarda Anti Hbs Antikor
} Düzeyleri- Kesitsel Bir Çalışma

\section{Anti Hbs Antibody Levels in Children Aged 5-18 years in a Family Medicine Outpatient Clinic- A Cross-Sectional Study}

\author{
Zerrin GAMSIZKAN ${ }^{1}(\mathbb{D})$, Mehmet Ali SUNGUR ${ }^{2}$ (D) , Ersen ÇEKIRGE $^{3}$ \\ ${ }^{1}$ Düzce Üniversitesi, Tıp Fakültesi, Aile Hekimliği Anabilim Dalı, Düzce, TÜRKiYE \\ 2 Düzce Üniversitesi, Tıp Fakültesi, Biyoistatistik Anabilim Dalı, Düzce TÜRKiYE \\ ${ }^{3}$ Düzce Merkez 7 Nolu Aile Sağlığı Merkezi, Düzce , TÜRkiYE
}

Öz.

Amaç: Bu çalışma; bir aile hekimliği polikliniğine başvuran 5-18 yaş arası çocuklarda serum Anti-Hbs antikor düzeyleri ile hepatit $B$ aşılanma durumlarını araştırmak için yapılmıştır.

Materyal ve Metod: Çalışma tanımlayıcı- kesitsel bir çalışmadır. Çalışmaya bir Aile Sağlığı Merkezine periyodik muayene ve okul sağık taramaları için başvuran 5-18 yaş arası 84 çocuk dahil edilmiştir. Çalışmaya dahil edilen çocukların ailesinden çocuğun aşılanma durumu, kronik hastalık varlığı, anne baba eğitim ve meslek bilgisini içeren kısa bir form doldurması istendi. Bu yanıtlarla çocukların cinsiyet, yaş ve Anti-Hbs düzeyi arasındaki ilişki sorgulandı. Düzce Halk sağlı̆̆ı laboratuarında Mikro-ELiSA yöntemi ile bakılan Anti-HBs düzeyi $10 \mathrm{mIU} / \mathrm{ml}$ nin üzerinde olan antikor değerleri seropozitif olarak kabul edildi.

Bulgular: Çalışmamıza alınan çocukların \%53,6 ( $n=45)^{\prime}$ sı erkek, \%46,4 ( $\left.n=39\right)^{\prime}$ ü kız çocuk idi. Çalışmamızdaki çocukların yaş ortalaması $12,13 \pm 2,73$ olarak tespit edildi. Cinsiyete göre anti-HBs seropozitiflik oranları arasında anlamlı bir fark bulunmamıştır $(p=0,627)$. Ancak, aşı yapılmamış çocukların yaş ortalaması aşı yapılmış olan çocuklara göre anlamlı olarak yüksek bulundu $(p<0,001)$. Aşılı olduğu anamnezi alınan 62 çocuğun $29^{\prime} u(\% 46,8)$ Anti-HBs düzeylerine göre seronegatif olarak tespit edilmiştir.

Sonuç: Çalışmamııın en önemli sonucu, aşılanmamış çocuklarda yaşın anlamlı olarak daha yüksek tespit edilmiş olmasıdır. Bu durum, ülkemizde bağışılama hizmetlerinin giderek daha etkin olduğunu düşündürmekle beraber, yaşı büyük olan çocukların hepatit B enfeksiyonuna karşı bağışıkık ya da taşıyıcılık durumunun araştırılması, birey ve toplum sağlı̆ı ıçin önemli bir adım olacaktır.

Anahtar Kelimeler: Bağışıklama, Anti- HBs, Çocuk, Hepatit B

Abstract

Background: This study was conducted to investigate serum Anti-Hbs antibody levels and hepatitis B vaccination status in children aged 5-18 years who applied to a family medicine outpatient clinic.

Materials and Methods: The study is a descriptive cross-sectional study. Eighty-four children between the ages of 5 and 18 who applied to a Family Health Center for periodic examinations and school health screenings were included in the study. The parents of the children included in the study were asked to fill in a short form containing the vaccination status of the child, the presence of chronic illness, education and occupation information of the parents. With these answers, the relationship between the children's gender, age, and Anti$\mathrm{Hbs}$ level was questioned. Anti-HBs level measured with Micro-ELISA method in Düzce Public Health Laboratory was accepted as seropositive.

Results: $53.6 \%(n=45)$ of the children included in our study were male and $46.4 \%(n=39)$ were female. The mean age of the children in our study was found to be $12.13 \pm 2.73$. No significant difference was found between antiHBs seropositivity rates according to gender $(p=0.627)$. However, age of the children not being vaccinated was found to be significantly higher than the vaccinated children $(p<0.001)$. Anti-HBs were detected as seronegative in $29(46.8 \%)$ of 62 children whose history was vaccinated.

Conclusion: The most important finding of our study is that the age was found to be significantly higher in unvaccinated children. Although this suggest that immunization services are increasingly effective in our country, investigation of immunity or carrier status against to hepatitis B infection in older children will be an important step for individual and public health.

Key Words: Immunization, Anti- HBs, child, Hepatitis-B
Sorumlu Yazar/Corresponding Author

Dr. Zerrin GAMSIZKAN

Düzce Üniversitesi, Tıp Fakültesi, Aile Hekimliği Anabilim Dalı, Düzce, TÜRKiYE

E-mail: zgamsizkan@yahoo.com

Geliş tarihi / Received: 23.04.2021

Kabul tarihi / Accepted: 05.07.2021

DOI: 10.35440/hutfd.926794 


\section{Giriş}

Hepatit B virüs (HBV) enfeksiyonu yol açtığı klinik durumlarla birlikte dünya çapında ciddi ve küresel bir sorundur (1). Gözlemci araştırmacılara göre, dünyada HBV enfeksiyonlarının tahmini sayısının 2016'da yaklaşık 292 milyon civarı olacağı öngörülmektedir (2). Ülkemizde ise HBV ile enfekte hasta sayısının 3-3,5 milyon arasında olduğu tahmin edilmektedir (3). HBV enfeksiyonu klinik olarak, asemptomatik taşıyıcılıktan siroz ve hepatosellüler kansere kadar geniş bir alanda görülen bir halk sağlığı problemi olduğundan etkilediği sağlık hizmeti alanı; birinci basamak koruyucu hizmetlerden başlayarak, üçüncü basamak olan araştırma hastanelerine kadar geniştir (4). Korunma olmadan HBV ile enfekte olan kişilerin\%25'inin ileri komplikasyonları olan karaciğer kanseri ve siroz gibi hastalıklardan dolayı kaybedildikleri belirtilmektedir (5). HBV enfeksiyonunun çeşitli bulaşma yolları vardır; enfekte olmuş kan veya vücut salgıları, cinsel temas, enfekte olmuş anneden yenidoğana geçme ve yakın aile ile temas bunların en bilinen bulaş yollarıdır (6). HBV enfeksiyonu ile mücadele, enfeksiyon kronikleştiğinde oluşan maddi yük ve sağlık komplikasyonları düşünüldüguünde enfeksiyon oluşmadan bulaşın önlenmesi oldukça önemlidir. HBV enfeksiyonuyla mücadele etmenin en etkili yolu, enfeksiyonu önlemek ve insanları ajanla maruziyetten önce aşılamaktır (7).

HBV enfeksiyonuna karşı geliştirilen HBV aşısı 1981'de FDA onayı almıştır. İlk olarak, plazmadan elde edilmiş olan aşı bu şekilde enfeksiyon bulaşma riski fazla ve ekonomik olarak maliyeti yüksek iken, 1986 'da rekombinant DNA teknolojisi ile üretilen aşı tercih edilir hale gelmiştir (8). Aşı uygulaması ile HBV enfeksiyonuna karşı etkin bir immünizasyondan bahsedebilmek için, anti-HBS seviyesinin 10mlU/ml'den yüksek olması gerekmektedir (9).

Ülkemizde 1998 yılından itibaren çocukluk çağı aşılamalarına HBV enfeksiyonuna karşı rutin aşılama uygulaması eklenmiştir. 1998-2002 yılları arasında takvim; üçüncü, dördüncü ve dokuzuncu ayların sonunda şeklinde uygulanıyorken, 2003-2008 yılları arasında doğumda, ikinci ve dokuzuncu ayın sonunda aşılama şeklinde devam etmiştir. Rutin çocuk aşılamalarının yanı sıra Sağlık Bakanlığının 2005-2008 yılları arasında ilköğretim kohortu HBV aşılamaları, 20082009 yılları arasında da ortaöğretim HBV aşılama çalışmaları uygulanmıştır (10). 2008 yılından itibaren genişletilmiş aşılama kapsamında yayınlanan genelge ile HBV bağışıklama takvimi; doğumda, birinci ve altıncı ayın sonunda uygulanmaya geçilmiş olup bu uygulama halen devam etmektedir (11).

HBV bağışıklaması sonrası hepatit B yüzey antijenine karşı oluşturulan antikorların titresi $10 \mathrm{mlU} / \mathrm{ml}$ 'den az olduğunda aşılama başarısızlığı ya da düşük yanıt olarak kabul edilmekte olup bu bireylerin HBV'den etkili bir şekilde korunmadığı ve endemik bölgelerde bu virüsle enfekte olma riski bulunduğu belirtilmektedir (12). Bu bağlamda son yıllarda yükseltici doz uygulaması konusundaki çalışmalar da devam etmektedir (13). Wu ve arkadaşlarının (14) yaptığı çalışma ilk aşılamadan sonraki amnestik yanıtın \%4,35 hastada oluşmadığı ve deneklerin immünolojik hafızalarını kaybettiğini göstermektedir. Amnestik yanıt oluşmayan hasta oranı düşük olsa da her bir hastanın koruyucu sağlık hizmetinden yararlanarak doğru yönlendirilmesi önemlidir. Bir diğer yükseltici doz müdahalesi sonuçlarını sunan çalışmada da yenidoğan döneminde yapılan HBV bağışıklamasının, bağışıklık belleği sayesinde enfeksiyona karşı koruyuculuğu olduğunu belirtirken, erken yaşta zayıf yanıt veren HBV aşılarının\% 31.9'unun çocukluktan sonraki dönemde HBV enfeksiyonuna karşı duyarlı olabileceği vurgulanmaktadır (15).

Ülkemizde yapılmış bağışıklama sonuçlarını araştırmak amacıyla yapılmış çalışmalar özellikle çocukluk yaş grubunda sınırlı sayıdadır. Çalışma planını oluşturma aşamasında yaptığımız literatür araştırmasından elde ettiğimiz verilere göre, özellikle Hepatit B aşısının rutin aşı programına alınmasından sonraki dönemde seroprevalans durumu ile ilgili bilgilerin kısıtlı olduğu yönündedir (16). Ayrıca son yıllarda tüm bilgilendirme ve farkındalık çalışmalarına rağmen ülkemizde ve Dünya'da çeşitli nedenlerin bağışıklama çalışmalarında aksamaya yol açtığı bildirilmektedir (17).

Çalışmamızda ülkemizde HBV aşılama programı rutin uygulanmaya başlamasından sonraki dönemde bölgemizdeki çocukların HBV'e karşı aşılanma durumunu ve anti-HBs düzeylerini tespit etmeyi amaçladık.

\section{Materyal ve Metod}

Çalışmamızı planlama aşamasında rutin periyodik çocuk izlemleri ve Milli Eğitim Bakanlığı tarafından okul taramaları için kayıtlı aile hekimlerine yönlendirilen 5-18 yaş arası öğrencilerin muayene sonucunda gerekli olan durumlarda istenen tetkik sonuçlarından çocuklardaki anti-HBs düzeylerinin değerlendirilebileceği öngörüldü. Bu çalışma için gerekli etik kurul onayı Düzce Tıp Fakültesi'nden ve Düzce Halk Sağlığı Müdürlüğü aracılığıyla Türkiye Halk Sağlığı kurumundan alındı. (Etik kurul numarası: 2017/154, 25.12.2017). Çalışmada, Düzce ili 7 Nolu Aile Sağlığı Merkezinde tanımlı olan iki aile hekimliği biriminde Eylül 2017- Nisan 2018 tarihleri arasında anti-HBs antikor düzeyi bakılan, ailesi çalışmaya katılmayı kabul eden 84 çocuğun verisi kullanılmıştır.

Çalışmaya alınan çocukların yaşı, cinsiyeti, aşılanma durumu, anne ve baba eğitim durumu sorgulandığı kısa bir demografik bilgi yanında aile hekimliği bilgi sisteminden çocuğun bağışıklanma durumu hakkında veriler kullanıldı. Aile hekimliği bilgi sisteminden aşı bilgisi olmayan çocukların bağışıklanma bilgisi ailesinden anamnez ile alındı. Çalışmada aşı cevabını etkileyebilecek herhangi bir immün sistem hastalığı ve kronik hastalığı olmayan 84 çocuğun verisi kullanıldı. Düzce Halk sağlığı laboratuvarında Mikro-ELiSA yöntemi ile bakılan Anti-HBs düzeyi $10 \mathrm{mlU} / \mathrm{ml}$ 'nin üzerinde olan antikor değerleri seropozitif kabul edildi.

\section{istatistiksel Analiz}

İstatistiksel analizler SPSS v.22.0 paket programında yapıl- 
mıştır. Tanımlayıcı istatistiklerde sayısal değişkenler için ortalama \pm standart sapma veya mediyan (minimum-maksimum), kategorik değişkenler için sayı ve yüzde kullanılmıştır. Verilerin normal dağılımına uygunluğunun araştırımasında Kolmogorov-Smirnov testinden yararlanılmıştır. Sayısal değişkenler için grup karşılaştırmalarında Independent Sample t testi kullanılmıştır. Kategorik değişkenlerin analizinde beklenen değer kuralına bağlı olarak Pearson ki-kare veya Fisher-Freeman-Halton testi kullanılmıştır. İstatistiksel önemlilik için $p<0,05$ değeri kriter olarak kabul edilmiştir.

\section{Bulgular}

Çalışmamıza anti-HBs düzeyleri bakılmış olan 84 hasta dahil edilmiştir. Çalışmamıza alınan çocukların \%53,6 ( $n=45)^{\prime} \mathrm{s}$ । erkek, \%46,4 ( $n=39$ )'ü kız çocuk idi. Çalışmamızdaki çocukların yaş ortalaması $12,13 \pm 2,73$ yıl olarak tespit edilmiştir. Çalışmamıza katılan çocukların anti-HBs median düzeyi 10,65 (2,97-41,55) [min: 0,15-max: 337,58] idi. Çalışmamıza aldığımız 5-18 yaş arası çocuklardaki anti-HBs pozitifliği $\% 53,6(n=45)$ olarak tespit edilmiştir. HBV aşısı olduğu bilinen 62 çocuğun \%46,8 ( $n=29)^{\prime}$ 'inde anti-HBs antikoru seronegatif olarak tespit edilmiştir. HBV aşı bilgisine aile hekimliği bilgi sisteminden ulaşılamayan çocukların Anti-HBs antikoru seronegatiflik oranı ise $\% 45,5(n=10)$ olarak bulunmuştur. Çalışmamızdaki aşılanmamış çocuklarda yaşın anlamlı olarak daha yüksek olduğu tespit edilmiştir $(p<0,001$, Tablo 1).

Tablo 1. Yaşa Göre Çocukların Aşılanma Durumu

\begin{tabular}{|l|c|c|c|}
\hline & $\begin{array}{c}\text { Aşılanmış çocuk } \\
(\mathbf{n}=\mathbf{6 2})\end{array}$ & $\begin{array}{c}\text { Aşılanmamış çocuk } \\
(\mathbf{n}=\mathbf{2 2})\end{array}$ & P değeri \\
\hline Yaş, yıl & $11,09 \pm 2,38$ & $14,91 \pm 2,62$ & $<\mathbf{0 . 0 0 1}$ \\
\hline
\end{tabular}

Çalışmamızdaki sonuçlar cinsiyete göre değerlendirildiğinde kız ve erkek çocukları arasında anti-HBs seropozitifliği açısından anlamlı bir fark tespit edilmemiştir $(p=0,627$, Tablo-2).

Tablo 2. Cinsiyete Göre Anti-HBs Antikor Düzeyleri

\begin{tabular}{|c|c|c|c|}
\hline Anti HBs düzeyi & $\begin{array}{c}\mathrm{K} \mathbf{} \\
(\mathbf{n = 3 9 )}\end{array}$ & $\begin{array}{c}\text { Erkek } \\
(\mathbf{n}=\mathbf{4 5})\end{array}$ & \multirow{2}{*}{ P değeri } \\
\hline$<10 \mathrm{mlU} / \mathrm{ml}, \mathbf{n}(\%)$ & $17(43,6)$ & $22(48,9)$ & \multirow{2}{*}{0,627} \\
\hline$>10 \mathrm{mlU} / \mathrm{ml}, \mathbf{n}(\%)$ & $22(56,4)$ & $23(51,1)$ & \\
\hline
\end{tabular}

Çalışmamızdaki hastaların anne ve baba eğitim durumuna göre Anti-HBs antikor düzeyleri (sırasıyla $p=0,783$ ve $p=0,188$ ) ve çocuklarını aşılatma durumu (sırasıyla $p=0,243$ ve $p=0,135)$ arasında anlamlı bir ilişki tespit edilmemiştir (Tablo 3).

\section{Tartışma}

Ülkemizde aşılanma oranlarında artış olduğu bildirilse de tüm dünyada da olduğu gibi çeşitli sebeplerle bağışıklama çalışmalarının sürekliliği için uyanık olmak gerektiği vurgu- lanmaktadır (18). Bağışıklama hizmetinin sonuçlarını gözlemleyebilmek amacıyla yaptığımız çalışmamıza aldığımız 518 yaş arası çocukların yarısından fazlasında anti-HBs antikor pozitifliği tespit edilmiş olup Al-Ghamdi ve arkadaşlarının (19), 14-24 yaş arasındaki 238 hastada HBV aşılamasının uzun dönem koruyuculuğunu araştırdıkları çalışmada da benzer sonuçlar bildirilmiştir. Livramento ve arkadaşlarının (20) 10-15 yaş arası çocuklarda yaptıkları çalışmada antiHBs antikor pozitifliği \%49,9 Tayland'da, Chongsrisawat ve arkadaşlarının (21) 6213 hasta ile ve 6 ay-60 yaş arası hastalarla yaptığı bir çalışmada ise anti-HBs antikor pozitifliği \% 41,6 olarak bildirilmiştir. Ülkemizde yapılan Van yöresinde 0-18 yaş arası 1332 çocuğun HBV sıklığı, seropozitifliği ve aşılanma durumunun belirlenmesi amacıyla yapılan çalışmada ise anti-HBs antikor pozitifliği \%71,3 olarak bildirilmiştir (22). Yapılan çalışmalarda tespit edilen antikor pozitifliğinin değişik oranlarda olmasının sebebinin çalışma yapılan hasta grubunun yaş aralığı, çalışma bölgesindeki sosyo-ekonomik farklılıklar ve değişik bağışıklama protokollerine bağlı olabileceği düşünülmektedir. Epidemiyolojik bir araştırma sonuçlarına göre ülkemizde genel olarak anti-HBs prevalansı \%20,6-\%52,3 gibi geniş bir aralık oranlarında olduğu ve ülkemizin orta düzeyde endemik ülkeler grubuna girdiği belirtilmektedir (16). Azarkar ve arkadaşları (23) koruyucu antikor düzeylerinin immün hafıza ile bireyleri koruduğu bilgisinin yanı sıra bölgesel düzeyde enfeksiyon risklerinin farklı olabileceğini ve takip çalışmalarının devam etmesi gerektiğini vurgulamaktadır. Başka çalışmalarda da koruyucu sağlık uygulamaları ile bağışıklama hizmetlerinin etkinliğinin değerlendirilebilmesi için uzun dönemli takip çalışmalarının yapılması gerektiği vurgulanmakta (24) olup yapılan araştırmalarla anti-HBs düzeylerinin takip edilmesi ile elde edilen düşük antikor düzeyleri ya da hiç antikor cevabının oluşmadığı durumlar göz önüne alındığında orta endemik düzeyde olan ülkemiz açısından bağışıklama sonrası antikor takibinin faydalı olacağı düşünülmektedir.

Çalışmamızda cinsiyete göre değerlendirildiğinde kız ve erkek çocuklar arasında anlamlı olarak bir fark tespit edilmemiştir. Ankara'da 0-18 yaş arası çocuklarda retrospektif olarak anti-HBs düzeyleri değerlendirme sonuçlarına göre kız çocuklarda erkek çocuklara göre anlamlı olarak seropozitiflik daha yüksek bulunmuştur (25). 2018 yılında 335 tıp fakültesi öğrencisinin anti-HBs sonuçlarının değerlendirildiği bir çalışma sonuçları da kız öğrencilerin antikor düzeylerinin erkek öğrencilerden anlamlı olarak daha yüksek olduğunu göstermektedir (26). Buna karşılık çalışmamızdaki sonuçlarla benzer bir şekilde, İşcan ve arkadaşlarının (27) 1-12 yaş arası 180 çocuk üzerinde yaptıkları çalışmalarında, cinsiyete göre anti-HBs seropozitifliği arasında anlamlı bir fark tespit edilmediği belirtilmiştir. Yine Kutlu ve arkadaşları (28) sağIık taraması için gelen 519 hastane personelinde bakılan antikor düzeylerinin sonuçlarına göre anti-HBs düzeyi ile cinsiyet arasında herhangi anlamlı bir fark tespit etmemişlerdir. 
Tablo 3. Anne- baba eğitim durumu ile Anti-HBs ve Aşı Yaptırma Durumu Arasındaki İlişki

\begin{tabular}{|c|c|c|c|c|c|c|c|c|}
\hline \multirow[b]{2}{*}{ Anti-HBs } & \multicolumn{3}{|c|}{ Anne Eğitim Durumu } & \multirow[b]{2}{*}{$\mathbf{P}$} & \multicolumn{3}{|c|}{ Baba Eğitim Durumu } & \multirow[b]{2}{*}{$\mathbf{P}$} \\
\hline & $\begin{array}{l}\text { İlkokul } \\
\text { (n=73) }\end{array}$ & $\begin{array}{l}\text { Lise } \\
(n=8)\end{array}$ & $\begin{array}{l}\text { Üniversite } \\
\quad(n=3)\end{array}$ & & $\begin{array}{l}\text { İlkokul } \\
\text { (n=68) }\end{array}$ & $\begin{array}{c}\text { Lise } \\
(n=14)\end{array}$ & $\begin{array}{c}\text { Üniversite } \\
\quad(n=2)\end{array}$ & \\
\hline$<10 \mathrm{mlU} / \mathrm{ml}$ & $33(45,2)$ & $4(50,0)$ & $2(66,7)$ & \multirow{2}{*}{$0,783^{*}$} & $29(42,6)$ & $8(57,1)$ & $2(100)$ & \multirow{2}{*}{$0,188^{*}$} \\
\hline$>10 \mathrm{mlU} / \mathrm{ml}$ & $40(54,8)$ & $4(50,0)$ & $1(33,3)$ & & $39(57,4)$ & $6(42,9)$ & $0(0,0)$ & \\
\hline Aşı Yaptırmış & $52(71,2)$ & $8(100)$ & $2(66,7)$ & \multirow{2}{*}{$0,243^{*}$} & $47(69,1)$ & $13(92,9)$ & $2(100)$ & \multirow{2}{*}{$0,135^{*}$} \\
\hline Aşı Yaptırmamış & $21(28,8)$ & $0(0,0)$ & $1(33,3)$ & & $21(30,9)$ & $1(7,1)$ & $0(0,0)$ & \\
\hline
\end{tabular}

* Fisher-Freeman-Halton test

Çalışmamızda çıkan sonuçlara göre anne-baba eğitim durumu ile anti-Hbs antikor seviyeleri ve çocuklarını aşılatma durumu arasında anlamlı bir ilişki bulunmamıştır. Benzer şekilde İstanbul Üniversitesi Tıp Fakültesinde yapılan bir çalışmada da anti-HBs seropozitifliği ve annelerin çalışma durumu ve eğitim düzeyleri ile çocukların cinsiyeti arasında istatistiksel olarak anlamlı ilişki saptanmamıştır (29). Bununla birlikte annenin eğitim durumu ile çocuklarının aşılarını tamamlama konusunda pozitif yönde ilişki olduğu söylenmekte olup (30), anne baba eğitim durumunun yüksek olmasının çocuklarını aşılatma oranını arttırdığını söylenen çalışmalar mevcuttur (31).

Çalışmamızda metodoloji bölümünde de bahsettiğimiz gibi aşısı yapılmamış olarak bildirilen çocukların aşı kartlarına ulaşılamadığından ve Aile Hekimliği bilgi siteminden de görülemediğinden bağışıklama bilgisi ailesinden alınmış olup, aşılanmamış anamnezi olan 22 çocuğun yarısından çoğunun anti-HBs antikoru seropozitif olarak tespit edilmiştir. Bu sonuç itibariyle bu çocukların da 1998 yılından beri başlayan bağışıklama hizmetlerinden yararlanmış olabileceği, ailesinin aşı olduğu bilgisini sağlıklı bir şekilde hatırlayamadığı düşünülmektedir. Çalışma sonuçlarımıza göre, aşılanmamış çocukların yaşı anlamlı olarak daha yüksek tespit edilmiştir. Benzer sonuçlar ülkemizde yapılan başka çalışmalarda da gösterilmiştir (16).

Biz bu çalışmamızda anti-HBs düzeyleri seronegatif kabul edilen $10 \mathrm{mIU} / \mathrm{ml}$ altındaki çocukları ve ailelerini bilgilendirerek, ilgili bölümlere yönlendirdik. Hastalara hatırlatma dozu yapma ya da herhangi başka bir girişim için etik kuruldan herhangi bir iznimiz olmadığı için vakaların Enfeksiyon Hastalıkları tarafından değerlendirilmesini uygun gördük. Tartışmada yer alan literatür bilgisine göre bazı ülkelerde çocuklara belli yaş dönemlerinde hatırlatma dozu yapıldığını görmekteyiz. Çalışma kapsamında olmamakla birlikte okuyucuya katkı sağlaması açısından hem hatırlatma dozu hem de rutin HBV bağışıklaması hakkında aşı komitelerinin tavsiyelerine bakacak olursak; 2017'de Kanada Ulusal Bağışıklama Danışma Komitesi Hepatit Çalışma Grubu, kilit soruları gözden geçirerek, kanıt incelemesi yaptığını görmekteyiz. Önlenecek hastalık yükü, aşının güvenliği, immünojenikliği, etkinliği ile ilgili hususlar göz önüne alındığında, aşı kullanımı için önerilerde bulundu. Komite; bebeklik döneminde önerilen bir HBV immünizasyon programının tamamlanmasının ardından immünitesi sağlıklı bireyler için rutin güçlendirici HBV aşı dozlarını önermemektedir (32). Komitenin bir diğer önerisi ise immün sistemi baskılanmış bireylerin immünizasyonunu takiben, anti-HBs antikor seviyelerinin başlangıçtaki yıllık izlemesinin dikkate alınabileceği ve HBV için aşılama, belirlenen il ve bölge programlarına göre yapılması şeklindedir.

Çalışmamızın sınırlılıkları; çalışmamız kesitsel bir çalışma olduğundan sonuçları itibariyle Türkiye'de ve bölgemizdeki HBV aşılaması sonuçları şeklinde genelleştirilemez. Aşı olmadığı tespit edilen çocukların çoğunlukla Sağlık Bakanlığı Aile Hekimliği uygulaması öncesi döneme ait olan çocuklar olduğundan ve sistem üzerinde kayıtlı aşı görünmediğinden sadece ailesinin beyanı esas alınmıştır. Ayrıca hasta sayımız az olduğundan dolayı hastaları yaş gruplarına ayıramadığımızdan antikor düzeylerinin yaş gruplarına göre değerlendirilmesi pek mümkün olmadı. İlerde yapılacak çalışmalarda daha fazla hasta sayısı ve zaman aralığı ile çocukları yaş gruplarına ayırarak antikor düzeyinin tespiti ve korelasyonel çıkarımlar tavsiye edilebilir.

Çalışmamızda ortaya çıkan en önemli sonuç aşılanmamış çocuklarda yaşın anlamlı olarak daha yüksek tespit edilmiş olmasıdır. Bu durum ülkemizde bağışıklama hizmetlerinin giderek daha etkin olduğunu göstermekle beraber, yaşı büyük olan çocukların HBV antijen ve antikorunun kontrol edilmesini gerektirmektedir. HBV enfeksiyonunun yol açtığı hastalık sonuçlarının ciddi olması ve aşı ile etkin bir şekilde önlenebiliyor olması bakımından avantajı düşünüldüğünde bağışıklama hizmetlerinin takibi önemlidir. Özellikle aşı karşıtlığının arttığı günümüzde, bağışıklama hizmetlerinin sonuçlarının takip edilmesi koruyucu sağıık hizmetlerinin planlanmasında yol göstericidir.

Etik onam: Bu çalışma için gerekli etik kurul onayı Düzce Tıp Fakültesi'nden ve Düzce Halk Sağlığı Müdürlüğg̈ aracılığıyla Türkiye Halk Sağlığı kurumundan alındı. (Etik kurul numarası: 2017/154, 25.12.2017).

\section{Yazar Katkıları:}

\section{Konsept: Z.G.}

Literatür Tarama: Z.G., M.A.S.

Tasarım: Z.G., E.C.

Veri toplama: Z.G., E.Ç.

Analiz ve yorum: Z.G., E.C., M.A.S.

Makale yazımı: Z.G., M.A.S.

Eleştirel incelenmesi: , M.A.S.

Çıkar Çatışması: Herhangi bir çıkar çatışmamı bulunmamaktadir.

Finansal Destek: Araştırma kapsamında herhangi bir kurum ya da kuruluştan finansal destek sağlanmamıştır. 


\section{Kaynaklar}

1. US Centers for Disease Control and Prevention. The ABCs of Hepatitis. 2012.http://www.cdc.gov/hepatitis/resources/proffessionals/PDFs /ABCTable-BW.pdf adresinden 10.07.2019 tarihinde erişilmiştir.

2. Polaris Observatory Collaborators. Global prevalence, treatment, and prevention of hepatitis B virus infection in 2016: a modelling study. Lancet Gastroenterol Hepatol. 2018;3:383403.

3. Tozun $N$, Özdoğan $O$, Çolakoğlu $Y$. A nationwide prevalence study and risk factors for hepatitis A, B, C, D infections in Turkey. Hepatology. 2010;52:697.

4. Walter SR, Thein HH, Amin J, Ward K, Law MG, George J, et al. Trends in mortality after diagnosis of hepatitis B or C infection: 1992-2006. J Hepatol. 2011;54:879-86.

5. Mitchell T, Armstrong GL, Hu DJ, Wasley A, Painter JA. The increasing burden of imported chronic hepatitis B--United States, 1974-2008. PLoS One. 2011;6:e27717.

6. Ragheb M, Elkady A, Tanaka Y, Murakami S, Attia FM, Hassan AA et al. Multiple intrafamilial transmission patterns of hepatitis B virus genotype D in North-eastern Egypt. J Med Virol. 2012;84:587-95.

7. Bruce MG, Bruden D, Hurlburt D, Zanis C, Thompson G, Rea $L$, et al. Antibody Levels and Protection After Hepatitis B Vaccine: Results of a 30-Year Follow-up Study and Response to a Booster Dose. J Infect Dis. 2016;214:16-22.

8. Szmuness $W$, Stevens CE, Harley EJ, Zang EA, Oleszko WR, William DC, et al. Hepatitis $B$ vaccine: demonstration of efficacy in a controlled clinical trial in a high-risk population in the United States. N Eng J Med. 1980;303:833-41.

9. Kim DK, Riley LE, Harriman KH, Hunter P, Bridges CB. Advisory Committee on Immunization Practices Recommended Immunization Schedule for Adults Aged 19 Years or Older - United States, 2017. MMWR Morb Mortal Wkly Rep. 2017;10;66:136-8.

10. Türkiye Anne, Çocuk ve ergen sağlığı Enstitüsü. Prof. Dr. Esma Sarıkaya.UlusalaşıProgramıTarihçemiz.https://www.tuseb.gov.tr/enstitu/tacese/yuklemeler/ekitap/ASI/ulusal_asi_takvimi_tarihcemiz1.pdf

11. T.C. Sağlık Bakanlığı, Genişletilmiş aşı programı hakkında genelge. https://www.saglik.gov.tr/TR,11080/genisletilmis-bagisiklama-programi-genelgesi.html adresinden 20.07.2019 tarihinde erişilmiştir.

12. Li $X, X u Y$, Dong $Y$, Yang $X, Y e B$, Wang $Y$, et al. Monitoring the efficacy of infant hepatitis $B$ vaccination and revaccination in 0 - to 8-year-old children: Protective anti-HBs levels and cellular immune responses. Vaccine. 2018;25;36:2442-2449.

13. Barro $M$, Valea $D$, Ouermi $S A$, Sessouma $S$, Sanogo $B$, Ouattara IAB, et al. Serological profile of hepatitis $B$ in children after the introduction of its vaccination in Burkina Faso. Pediatr Rep. 2019;11(4):8248.

14. Wu Z, Yao J, Bao H, Chen Y, Lu S, Li J, et al. The effects of booster vaccination of hepatitis $B$ vaccine on children 515 years after primary immunization: A 5-year follow-up study. Human vaccines \& immunotherapeutics. 2018;14:1251-6.

15. Zhu CL, Liu P, Chen T, Ni Z, Lu LL, Huang Fet al. Presence of immune memory and immunity to hepatitis $B$ virus in adults after neonatal hepatitis $B$ vaccination. Vaccine. 2011;13;29:7835-41.

16. Nalbantoğlu B, Nalbantoğlu A, Külcü NU, Say A. Dokuz Ay - 8 Yaş Arası Çocuklarda Hepatit B Seroprevalansı ve Aşılanma
Durumları. Çocuk Dergisi. 2010;10:116-21.

17. Gür E. Aşı kararsızı̆̆g - aşı reddi. Turk Pediatri Ars. 2019;54:12.

18. Yüksel HA, Topuzoğlu A. Aşı redlerinin artması ve aşı karşıtlığını etkileyen faktörler. ESTÜDAM Halk Sağlığı Dergisi. 2019;4 :244-58.

19. Al Ghamdi SS, Fallatah HI, Fetyani DM, Al-Mughales JA, Gelaidan AT. Long-term efficacy of the hepatitis $B$ vaccine in a high-risk group. J Med Virol. 2013;85:1518-22.

20. Livramento Ad, Cordova CM, Scaraveli NG, Tonial GC, Spada C, Treitinger A. Anti-HBs levels among children and adolescents with complete immunization schedule against hepatitis $B$ virus. A cross-sectional study in Blumenau, State of Santa Catarina, Brazil, 2007-2008. Rev Soc Bras Med Trop. 2011;44:412-5.

21. Chongsrisawat $V$, Yoocharoen $P$, Theamboonlers $A$, Tharmaphornpilas $\mathrm{P}$, Warinsathien $\mathrm{P}$, Sinlaparatsamee $\mathrm{S}$ et al. Hepatitis $B$ seroprevalence in Thailand: 12 years after hepatitis $B$ vaccine integration into the national expanded programme on immunization. TropMed Int Health. 2006;11:1496-502.

22. Avni K, Erbey MF, Okur M, Sal E, Üstyol L, Bektaş MS. Van Yöresinde 0-18 Yaşları Arasındaki Çocuklarda Hepatit B Virusu Seropozitifliği ve Aşılanma Durumu. J Pediatr Inf. 2011;5:1325 .

23. Azarkar Z, Ebrahimzadeh A, Sharifzadeh G, Ziaee M, Fereidouni $M$, Taheri F. Persistence of immunity to hepatitis $B$ vaccine as infants, 17 years earlier. Caspian J Intern Med. 2018;9:184-8.

24. Su FH, Cheng SH, Li CY, Chen JD, Hsiao CY, Chien CC et al. Hepatitis $B$ seroprevalence and anamnestic response amongst Taiwanese young adults with full vaccination in infancy, 20 years subsequent to national hepatitis vaccination. Vaccine. 2007;25:8085-90.

25. Altan H, Demirtaş S, Taş D, Budakoğlu Ii. Ankara'da bir devlet hastanesine başvuran çocuklarda hepatit B seroprevalansının belirlenmesi. Ankara Med J. 2017;1:1-8.

26. Mahallawi W. Persistence of hepatitis surface of antibody and immun memory to hepatitis $b$ vaccine among medical college students in Madinah. Ann Saudi Med. 2018;38:413-9.

27. İşcan G, Taşar MA. Aşı şeması tamamlanan çocuklarda operasyon öncesi anti- Hbs düzeyinin değerlendirilmesi. Konuralp Tıp Dergisi. 2018;10:244-7.

28. Kutlu R, Demirbaş N. Sağlık taraması için başvuran hastane personelinde serum $\mathrm{HbsAg}$ ve Anti-Hbs düzeyleri ile Hepatit B aşılanma durumu. Turkish Journal of Family Medicine and Primary Care. 2016;10:136-41.

29. Süleyman A, Gökçay G, Badur S ve ark. Süt Çocukluğunda Hepatit B Aşısı Uygulanan Çocuklarda Serolojik Durumun Değerlendirilmesi. Mikrobiol Bul. 2011;46:47-56.

30. Abuya BA, Onsomu EO, Kimani JK, Moore D. Influence of maternal education on child immunization and stunting in Kenya. Matern Child Health J. 2011;15:1389-99.

31. Calhoun LM, Van Eijk AM, Lindblade KA, Odhiambo FO, Wilson $\mathrm{ML}$, Winterbauer $\mathrm{E}$ et al. Determinants and coverage of vaccination in children in western Kenya from a 2003 crosssectional survey. Am J Trop Med Hyg. 2014;90:234-41.

32. Henry B, Baclic O; National Advisory Committee on Immunization (NACl). Summary of the NACI Update on the Recommended Use of Hepatitis B Vaccine. Can Commun Dis Rep. 2017;43(5):104-6. 